\title{
Kızılelma Viyana, bir ümidin sönüsü
}

Vienna, the "red apple", a fading hope

Vienne, la "Pomme rouge ", un espoir qui s'efface

\section{Semih Tezcan}

\section{(2) OpenEdition}

\section{Journals}

Édition électronique

URL : https://journals.openedition.org/ceb/3934

DOI : 10.4000/ceb.3934

ISSN : 2261-4184

\section{Éditeur}

INALCO

\section{Édition imprimée}

Pagination : 43-49

ISBN : 978-2-85831-205-4

ISSN : 0290-7402

\section{Référence électronique}

Semih Tezcan, « Kızılelma Viyana, bir ümidin sönüsü », Cahiers balkaniques [En ligne], 41 | 2013, mis en ligne le 19 mai 2013, consulté le 06 juillet 2021. URL : http://journals.openedition.org/ceb/3934 ; DOI : https://doi.org/10.4000/ceb.3934

Ce document a été généré automatiquement le 6 juillet 2021

\section{cc) (†) 8}

Cahiers balkaniques est mis à disposition selon les termes de la Licence Creative Commons Attribution - Pas d'Utilisation Commerciale 4.0 International. 


\title{
Kızılelma Viyana, bir ümidin sönüsü
}

\author{
Vienna, the "red apple", a fading hope \\ Vienne, la "Pomme rouge », un espoir qui s'efface
}

\section{Semih Tezcan}

1 Robert Dankoff, kendisinin 30 yılı aşkın bir süre içinde edindiği deneyim sayesinde Seyahatnâme'de her şeyin bir anlamı ve önemi olduğunu, bunun ötesinde çoğu zaman bir yerde anlatılanların başka bir yerde anlatılanlarla bağlantılı olduğunu öğrenmiş, bize de öğretmiştir. ${ }^{1}$ Okuyucunun Çelebi, ilk kez karşılaştığında önemini, münasebetini, hatta ne olduğunu bile tam olarak kavrayamadığı bir hususu, Evliyâ Çelebi başka bir yerde yeniden okuyucunun karşısına çıkarır, hatırlatır, eklemeler veya göndermeler yapar, kimi zaman açıklamalar da verir. Ama kimi zaman bir açılama vermez. Böyle durumlarda onun ne demek istediğini, neyi kastettiğini bulup çıkarmak, kavramak tıpkı bilmece çözer gibi- okuyucuya düşen bir görev olarak kalır.

2 Seyahatnâme'deki bilmeceleri çözebilmek için birbirine bağlı birkaç koşul vardır: 1) Birincisi, şüphesiz okuyucu, orada bir çeşit bilmecenin saklı olduğunu kavrayacak ferasete sahip olmalıdır. 2) İkincisi: Okuyucunun Seyahatnâme metnini anlamaya niyeti olmalıdır, yani bu metni sadece bir başvuru kitabı olarak kullanmanın, onun içinde belli bilgiler aramanın ötesinde, uğraşılmaya değer bir metin olarak görmelidir. 3) Üçüncüsü, bağlantıların farkına varabilmesi için okuyucunun Seyahatnâme'yi çok uzun aralar vermeden baştan sona okumuş olması veya bu metinle sürekli uğraşması gereklidir. Elbette 10 büyük cildi uzun aralar vermeden baştan sona okumak kolay bir iş değildir. Ama Seyahatnâme'nin sadece belli bir bölümünü okuyup, o bölüm üzerinde çalışıp bütün eser hakkında sonuçlar çıartmaya kalkışmak yanlış bir tutumdur. 4) Dördüncüsü en önemli koşuldur; bu, Evliyâ'yı sık sık saçmalayan bir geveze olarak görmemektir.

3 Evliyâ Çelebi hayranlarından, Seyahatnâme'nin ilk altı cildini özetleyip sadeleștirerek (Türkçeleştirerek) yayımlamış olan Reşad Ekrem Koçu, Evliyâ’nın İkinci Viyana Kuşatması'ndan ve bu kuşatmanın başarısızlıkla sonuçlandığından habersiz kaldığını yazmıştı. Bu, Koçu'nun Seyahatnâme'nin tamamını, özellikle de 7. kitabı okumamış veya dikkatle okumamış- olduğunu ortaya koymaktadır. ${ }^{2}$ Eğer Koçu, 7. kitabı okumuş 
(veya yeterince dikkatle okumuş) olsaydı, Osmanlı devletinin Orta Avrupa'ya karşı bu son büyük seferinin sonucundan Evliyâ'nın pekâlâ haberdar olduğunu gösteren yansımaları mutlaka görürdü. ${ }^{3}$

Evliyâ Çelebi'nin bir başka hayranı, 7. kitaptan Viyana bölümünü Almancaya mükemmel bir biçimde tercüme edip zengin notlarla yayımlayan, böylelikle bir bakıma 20. yüzyılda Evliyâ Çelebi araştırmalarının yeniden hareketlenmesini ve önem kazanmasını sağlamış olan Avusturyalı tarihçi Richard Kreutel ise sanıyorum, Seyahatnâme'nin Viyana dişındaki bölümleriyle pek fazla ilgilenmemişti. ${ }^{4}$ Eğer Evliyâ'nın eserinin tamamını okumuş olsaydı (veya Viyana bölümü üzerinde çalışırken yaptığı gibi büyük dikkatle okumuş olsaydı) Evliyâ'nın "zihnindeki Viyana fethi" ni mutlaka o keşfeder, şimdi benim burada konuşmama gerek kalmazdı.

Demek istediğim şudur: Evliyâ Çelebi araştırmalarına, yani bilime çok hizmet etmiş olan Kreutel'in kitabında Kızıl Elma Viyananın fethi meselesine ilişkin birtakım eksiklikler vardır ve bunlar, kendisinin Seyahatnâme'nin bütünüyle değil, daha çok yedinci kitapla, yani Viyana'yla meşgul olmasından ileri gelmektedir. Eğer Kreutel eserin'nin tamamını dikkatle okumuş olsaydı, Kızılelma Viyana'nın fethi konusunda daha doğru bir sonuç çıkartabilirdi.

Ama tabii, o günün olanaklarını göz önünde tutmak gerekiyor. Kreutel'in Seyahatnâme üzerinde çalıştı̆̆ı onyıllarda (20. yüzyıl ortalarında) eserin iyi bir edisyonu yapılmış değildi. Herhalde elinde tam metin (yazmaların fotoğrafları) yoktu, mikrofilm getirtmek hâlâ güç ve oldukça masraflı bir işti. Bugün dijitalize metinlerle çalışıp saniyeler, dakikalar içinde taramalar yaparken 60-70 önceki araştırmacıların ne kadar kısitlı olanaklara sahip olduğunu unutmamalıyız.

Burada, Evliyâ'nın Viyana kuşatmaları için kullandığı lafz̧'ları ele almak istiyorum: Lafz, bir kelimedeki harflerin ebced hesabı'na göre değerlerinin toplamıla bir yıla işaret etme sanatıdır, bir tür tarih düşürmedir (Chronogram), aynı zamanda bir tür şifredir. Seyahatnâme'nin Topkapı Sarayı Bağdat Köşkü takımında laf̧̧'lar her yerde kırmızı mürekkeple yazılmıştır.

8 Kreutel, 7. kitap haricinde kalan yerlere dikkat etmediği için bu meselede doğru sonuca varmamış olsa da dikkatimizin yöneltilmesinde çok önemli bir adım atmıştır. Kreutel şunu ortaya koymuştur:

9 Evliyâ'nın ظalle lafzı (şifresi) ile 935'i yılını verir $(5=0$, $30=\mathrm{J}, 900=$ b) Kreutel, bu kelimeyi zulla 'bulut' olarak okumuş ve bunun birinci Viyana kuşatmasının hicrî tarihi (= milâdî 1529) olduğunu, bu tarihin doğru olduğunu belirlemiştir. Bunun yanında geçen غنانم ġānim vem lafzlarından birincisinin 1091, غنم 40) ikincisinin 1090 sayısını gösterdiğini( $40=0=0=0$, $1000=\dot{\varepsilon}^{5}$ yazan Kreutel, olması Türklerin bu yıllarda Viyana ile ilgili herhangi bir girişiminin olmadığını belirtmiş, Evliyâ'nın bu şifrelerini karmaşık bir yoldan açıklamaya çalışmıştır. Bugün için geçerli olmayan bu açıklamayı özetlemeden geçmek istemiyorum:

Kreutel şunları söyler: 1090 ve 1091 yılları, miladî 16.2.1679 ile 20.01.1681 arasına denk düşer. Evliyâ Çelebi'nin Simon Petrus'un ağzından Birinci Viyana Kuşatması için telaffuz ettirdiği zulla 935 "sonradan uydurma" bir kehanettir (Pseudoprophezeiung). Evliyâ bunu 1683 'ten sonra eseri üzerinde değişiklikler yaparken metne katmıştır. Buna karşıllk 1090 ve 1091 tarihlerini gösteren ġānim ve ġunem, Evliyâ Çelebi'nin eserini ilk kez kaleme aldığında metne yerleştirdiği "hakiki" olmakla birlikte "doğru çıkmamış" 
olan (echten wenn auch nicht geglückten) kehanet denemesi sayılmalıdır. Aslında, 1683 'ten sonra eserini yeniden gözden geçirip değişiklikler yaptığı sırada Evliyâ'nın bu doğru çıkmamış kehaneti metinden çıkarması gerekirdi. ${ }^{6}$

Kreutel'in yanılgısı Topkapı Sarayı, Bağdat Köşkü takımı 308 no.lu yazmayı görmemiş, eski İstanbul baskısını esas alarak çalışmış olmasından kaynaklanmıştır. Kilisli Rifat Bilge, Seyahatnâme'nin 7. kitabını bilimsel yönteme uygun biçimde yayımlamıştı, fakat nedense burada metne ġunem غنيم غنم biçimini ise dipnotta vermişti. ${ }^{7}$ Kreutel'in bu nüsha farkına hiç önem vermediği anlaşllıyor, eğer Bilge'nin dipnotuna dikkat etmiş olsaydı, belki de sorunu kolayca çözebilecekti. Kreutel'den sonra metnin bu kısmı üzerinde duran tek araştırmacı Karl Teply olmuştur. Kreutel yanlış olarak $\dot{g} a \bar{n} i m$ ve ġunem biçimlerinden hareket etmişken, Teply doğru olarak ġānim ve ǵanìm biçimlerinden yola çıkar (s. 20 ve dev.), bu tarihlerin hurufîlere özgü sayı mantığı yöntemleriyle açıklanabileceğini ileri sürer, ancak somut bir açıklama önerisi getirmez.

Seyahatnâme'nin YKY-Dankoff baskısında da söz konusu kısım: Sonra lafz-ı gânim târîhinde lafz-ı ganîm târîhinde... biçiminde doğru okunmuş ${ }^{8}$ fakat soru işareti veya herhangi açıklayıcı bir not eklenmemiştir.

Meselenin çözümü için ilk önce, tarihçinin ve filologun her zaman yapması gereken şeyi yapmak, yani doğrudan doğruya yazmaya (varsa tıpkıbasıma) bakmak gerekiyor. Otograf ya da bir tür otograf ${ }^{9}$ olduğu bugün artık kesinleşmiş olan Bağdat Köşkü takımının 7. kitabında bu kısma baktığımızda, orada varak 55a'nın son satırlarında söz konusu yeri buluruz:

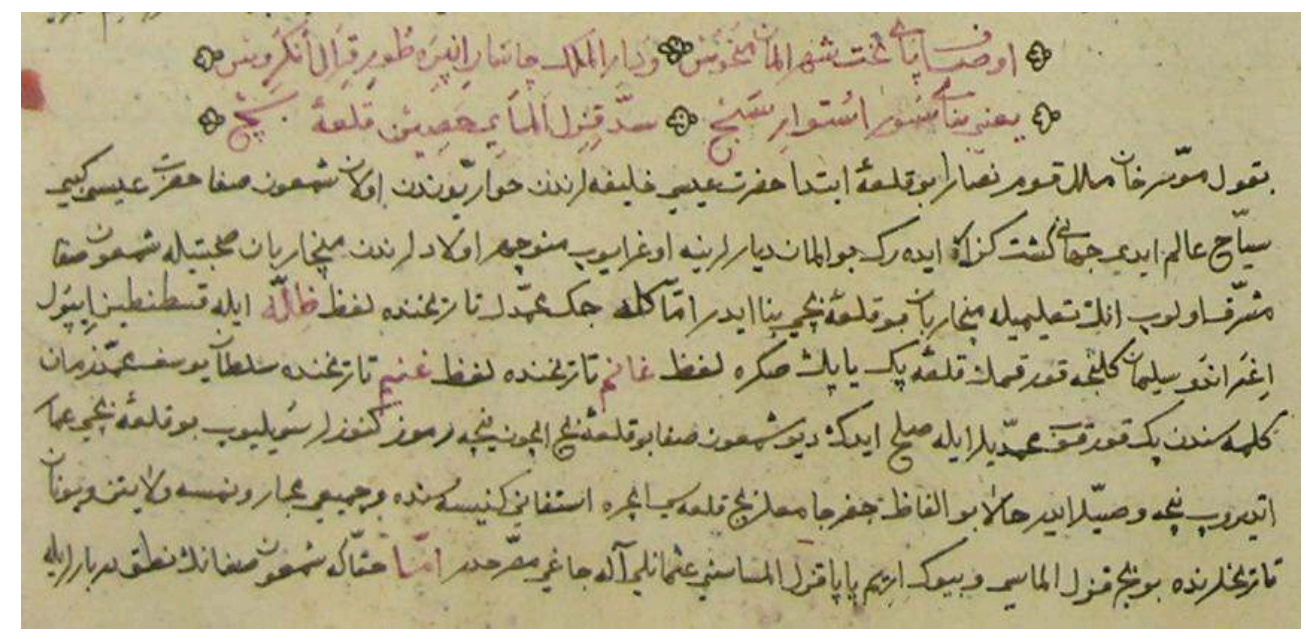

PHOTOgRAPHIE DE L'AUTEUR

Evṣāf-1 pāy-i taĤt-1 şehr-i Alman-1 menhūs ve dāru'l-mülk-i çāsār-1 inpiretor-1 ḳal-1 Ungurus, ya nī binā-yı sūr-1 üstüvār-1 Sebec, sedd-i Kızılelma-yı ḥașīn ḳal'a-i Beç.

Be-ḳavl-i müverriHāñ-1 milel-i ḳavm-i Nașārā bu ḳal'ayı ibtidā Ḥażret-i 'Īsā Hูalīfelerinden ḥavāriyyūndan olan şem'ūn-1 Șafā Ḥażret-i 'İsā gibi seyyāḥ-1 'ālem idi, \{hristiyan kavmi tarihçilerinin yazdığına göre bu kaleyi ilk kez Îsâ Peygamber'in havarîlerinden şem'ūn-1 Șafā (Simon Petrus), o da Hazret-i Îsâ gibi bir gezgin idi\}, 
cihānı geșt [ü] güzāâr ederek bu Alman diyārlarına ug̉rayup Menūçehr evlādlarından Mençaryan șoḥbetiyle şem'ūn-1 Șafā müşerref olup anıy ta'limmiyle Mençaryan bu ḳal'‘a-i Beçi binā eder. \{Dünyayı gezip dolaşarak bu Alman ülkelerine yolu düşüp Menûçehr evlâtlarından Mençaryan ile sohbet edip müşerref olup onun öğrettiği üzre Mençaryan bu Viyana kalesini inşa ettirir\}. "Ammā, gelecek Muhammedin tārīḨinde lafz-1 ẓılle ile Ḳostantinipol Ig̉rando Süleymān gelince ḳorkmay, kal'ayı pek yapıy. \{Ama, ileride doğacak olan Muhammed'in [hicrî] tarihine göre zılle şifresinde Kostantinipol Igrando Süleymân gelince korkmayın, kaleyi iyice tahkim edin\}. Șoyra lafz-1 gaānim tārīHuinde lafẓ-1 ganīm tārīHninde Sulțān Yūsuf Mehemmed-i zemān gelmesinden pek ḳorḳup Muhammedīler ile șulh edin" \{Sonra gaānim şifresi tarihinde, ganīm şifresi tarihinde o dönemin Muhammed'i, Sultan Yûsuf un gelmesinden pek korkup Muhammed'in dininden olanlarla barış yapın\} deyü şem'ūn-1 Șafā bu ḳal'a-i Beç içün niçe rümūz-1 künūzlar söyleyüp bu kal' a-i Beçi ' amār etdirüp niçe vașiyyetler eder. \{diye Simon Petrus, bu Viyana Kalesi hakkında birçok değerli rumuzlar söyleyip bu Viyana Kalesini yaptırıp birçok vasiyyetler eder\}.

Demek ki, esas alınması gereken biçim Kilisli Rifat Bilge'nin Hacı Beşir Ağa nüshasına göre metne aldığı غنم gunem değildir, Bilge'nin dipnotta vermiş olduğu غنيم ġanim biçimidir. İki şifre arasına [ve] eklenmesiyle sözdizimindeki aksama da giderilebilir. ${ }^{10}$ Bu takdirde, lafž-ı gānim tārīHinde [ve] lafž-ı ġanim tārïHinde ifadesini "gânim [1091] ve ganîm [1100] şifrelerinin gösterdiği yllarda" olarak anlamak mümkündür.

Ylllardan beri söylediğim gibi, Evliyâ Çelebi metninin leksikolojik öneminin çok belirgin biçimde ortaya çıkabilmesi için mutlaka bir tümdizin (concordance) yapılması gereklidir. Burada üzerinde duracağımız ġanim örneği böyle bir konkordansın leksikoloji meseleleri ötesinde, başka meselelerin çözümü için de işe yarayacağını açıkça ortaya koymaktadır.

Ganim yazılışını tespit ettikten sonra bu metne bir gün boyunca hayretle baktım. Ne demekti lafz-ı gānim ve lafz-ı ganim. Çeşitli değişiklikler yaparak burada bir çözüm bulmaya çalıştım. Evliyâ'nın Birinci Viyana kuşatması için kullandığı şifrenin (lafż) yani zılle'nin anlamı "bulut" idi; bununla ilgili bir kelime oyunu olup olmadığını araştırdım, sonuç olumsuz çıktı. ra Evliyâ'nın kullandığı şifrenin (lafž) yani غن ganim kelimesinin

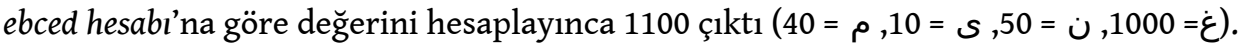

Evliyâ Çelebi, çoğu zaman lafz-ı ... demekle orada kullandığ kelimenin ebced hesabına göre karşıllğını kasteder. Başka bir deyişle: Bir olayın hangi yıl vuku bulduğunu veya bulacağını açıkça söylemez, okuyucuya buldurur. Tabii böyle oyunlar uygulayan birçok başka Osmanlı yazarı da vardır. Demek ki, eski zamanın okuyucuları böyle ebced hesap'll "bilmecemsi" ifadelerden, şifrelerden hoşlanıyorlarmış.

Bunun üzerine Seyahatnâme'deki lafž'ları taramaya başladım ve üç yerde daha lafz-ı ġanim'in Viyana'nın gelecekteki fethi, yani Evliyâ Çelebi'nin zihnindeki fethi ile ilgili olarak kullanılmış olduğunu belirledim. İşte, işin can alıcı noktası bu idi.

Çözüme geçiyoruz: Ebced hesabına göre lafž-ı 'in ġānim'in karşıllı̆ı 1091, lafž-ı ġanim'inki ise 1100'dür. Çözüm şudur: Evliyâ Çelebi, Viyana'nın ikinci muhasarada da alınmamış olduğunu (Kahire'de veya İstanbul'da) öğrenmiş, bundan üzüntü duymuştur. Bu hezimeti uzun boylu yazıp anlatmamıştır, zaten herhalde ayrıntıları bilmiyordu, öğrenememiști. Eğer o sırada Kahire'de bulunuyor idiyse, bu orada aldığı acı bir haber olarak kalmıştı onun için. Muhasaranın ve bozgunun yılını (1094) biliyordu, ama bu, 
belki onun için pek o kadar önemli değildi, asıl önemli olan güzel bir lafz̧ bulmaktı. Bunun için de -niçin öyle yaptığını daha sonra göreceğiz- $\dot{g} a ̄ n i m$ ve ġanīm şifrelerini seçti.

Bunlardan ebced'deki sayısal karşıllı̆ı 1091 olan birincisi (yani ġānim), İkinci Viyana Kuşatması için kullanılmış olan şifredir. Bu şifre, İkinci Viyana Kuşatması'nın tarihini (hicrî 1094 = miladî 1683) tutmuyor. Tutarsızlığın sebebini kesin biçimde belirlemek galiba hiçbir zaman mümkün olmayacaktır. Belki de burada Evliyâ için önemli olan sadece ġanim'e uyan bir şifre bulmaktı, ġānim'in 1094'ü tutmamasına aldırış etmemiş olabilir. Ama Evliyâ, bu kuşatmanın hangi yılda yapılmış olduğunu biliyordu, bunu Seyahatnâme VII.53a21-24'te yer alan “meczubun kehaneti” açıkça ortaya koymaktadır.

1094'teki muhasara (1683 İkinci Viyana Kuşatması) Seyahatnâme'de tek bir yerde geçer. $\mathrm{Bu}$ muhasaranın sonucunu Evliyâ kendisi telaffuz etmek istememiş, bir meczubun ağzından bir kehanet gibi söyletmiştir. Evliyâ Çelebi, 1665'te başında Kara Meḥmed Paşa'nın bulunduğu Osmanlı elçilik heyetinin bir üyesi olarak Viyana'da bulunduğu sırada, Avusturyalılar elçilik heyetini Viyana yakınında Otāò-ı Süleymān'ı gezmeye götürürler. Sözde Kânûnî tarafından yaptırılmış olan bu binayı Evliyâ pek beğenir, "İnşâallāh yine bizim içün ma'mûr olmuşdur. Hुudā yine dest-i İslāma müyesser ede" der. Bunun üzerine:"bir büdelā şekilli çāşnigìr ādem eydir: Allāh bu bāäı ve kal'a-i Beçi ḍoksan dördde İslām eline vermeye, zìrā bu bināları cümle Harâb ederler, dedikde gözleri țās-ı pür-Hūna döndü. Bir mecāzibūndan kimesne idi, ammā Allāh an-karïbü'z-zemān 'asker-i İslāmin kudūmiyle bu şehir Hōakine kadem bașmaǵı müyesser ede! Āmin." (VII.53a21-24) Evliyā’nın çāşnigir diye nitelediği bu adam heyette bulunan bir müslüman olmalıdır. Elçilik heyetinde çāşnigïrān ve kilarciyānlar bulunduğunu Evliyâ, VII.54a20'de söyler. Evliyâ, kurgulamasında bunlardan birini bu sözleri söylemek üzere öteki heyet üyeleriyle birlikte Otāğ-ı Süleymān'ı gezmeye götürmüştür. Bu adamın büdelā şekilli (derviş görünümlü) olması, kendisinden üstün mevkideki heyet üyeleri yanında bu gibi şeyler söylemeye cesaret etmesi, bir de herkesi tanıyan Evliyâ Çelebi'nin ondan adını anmadan bahsetmesi bunun bir kurgulama olduğunu açıkça gösteriyor. Evliyâ'nın, 1665 yllında telaffuz edilmiş gibi gösterdiği bu kehaneti 1683'teki İkinci Viyana Bozgunu'nun haberini aldıktan sonra eserine eklemiş olduğu açıktır.

Ganìm şifresinin ebced'deki sayısal karşıllığı ise 1100 'dür. Kendi ağzından İkinci Viyana Kuşatması üzerine bir şey söylemeye dili varmayan Evliyâ'nın zihninde ilerideki bir tarih var, "Viyana hicrî 1100'de alınabilir" demek istiyor. '1100'de Sulțān Yūsuf, yani IV. Mehmed (Avcı Mehmed) tekrar gidip Viyana'yı kuşatacak, belki de fethedecek. Ǵanim Şifresinin Seyahatname'de dört kere geçmesi bunu gösteriyor. Evliyâ'nın Kızıl Elma Viyana'nın alınacağı konusunda zayıf bir inancı, sönmekte olan bir ümidi var sanki. Kızl Elma Viyana bir gün fethedilebilir diyor, bunun tarihi olarak da 1100'ü münasip görmüş.

Bilindiği üzere hicrî 1000 yılı öncesinde, İslam âleminde hicrî 1000 yılının çok önemli bir yıl olacağı inancı yaygındı. Aynı şekilde Hristiyan âleminde de milâdî 1000 yılında çok büyük değişikliklerin olacağına inanılmaktaydı. Her iki âlemde bu bâtıl inancın tek sebebi 1000 sayısının yuvarlak bir sayı olmasıydı. Isște, 1000 gibi 1100 de yuvarlak bir sayıdır, 1000 'den sonra gelen ilk yuvarlak sayı. ${ }^{11}$ Evliyâ'nın eserinde hicrî 1000 ile ilgili bir şey bulmuyoruz, çünkü o doğduğunda hicrî 1000 yılı geçmişti ve o yılda olması beklenen olaylardan hiçbiri olmamıştı. Oysa Evliyâ'nın yaşadığı dönemde hicrî 1100 daha gelmemişti, o yıl gelince pek önemli şeyler olabilirdi, örneğin Viyana Türkler 
tarafından fethedilebilirdi! Aslında böyle şeylere meraklı olan Evliyâ, acaba 1100 tarihinde Viyana'nın alınacağına gerçekten inanıyor muydu? Yoksa bunun gerçekleşmeyecek bir arzu, bir düş olduğunu o da biliyor muydu? bağlamda büyük önem taşımakta ve yukarıdaki açıklamamı kanıtlamaktadır. Orhan Gazi'nin oğlu Süleymân Beşe ile Rumeli'ye geçen Otman Baba (Seyahatnâme'de 'Oșmān Baba) Avrupa'da birçok ülkeye gitmiş. Otman Baba, ayak bastığı yerlerin İslâm diyarı olması için dua edermiș: Ve Rūmeli kāfiristānında İşpanya ve Nemse ve Donkarḳız (18) ve Danimarka ve Rimpapa ve Paris vilāyetlerin geșt ü güzzār ederken "îlāhī İslām diyārı olup kenīseler, ma'bedgāh-ı müslimin ola (19) ba'de'l-elf mi'e" deyü nefes etmişlerdir. \{Ve Avrupa'nın hristiyan kesimlerinde İspanya'yı, Almanya'yı, Dunnkirchen'i, Danimarka'yı, Roma ve Paris vilayetlerini gezerken: “Ey Allahım, 1100'den sonra kiliseler müslüman ibadetgâhı olsun!” diye dua etmiş.) (Seyahatnâme, 8. kitap, 379a. 17-19).

Belki de Viyana'nın fethi için 1100 tarihini vermesinin başka sebepleri vardı. Evliyâ Çelebi, Kânûnî Sultan Süleymân'ın BirinciViyana Kuşatması'nın (1529) büyük bir hezimet olduğunu Kâimmakâm Mustafa Paşa'nın yüzüne karşı açıkça söyler, ona da tasdik ettirir: VIII.203a18 "Sulțānım Beçi ne șorar, ${ }^{12}$ (19) Beç bir menhūs kal'adır kim cemī'i Ungurus ve Alman ve yedi kralı̀ kilīdi ve Nemse çāsārının taHtgāhıdır kim cemīi $i$ yedi kral anı̀ ug̉uruna (20) kırılmag̉a ta' ahhüd etmişlerdir. Sulțān Süleymānı Beç altında kāfir bozup bārgāh-

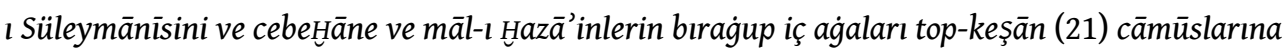
binüp ol şiddet-i şitāda Cān Kurtarana düşüp cān kurtardılar.[...] (22) ... Niçe tevārīin-i mu'teberelerde Süleymān Hुānı Beçde münhezim (23) olduğu mufașsalan tahrīr olunmuşdur." Evliyâ'nın bu sözlerini cevaplandırırken Mustafa Paşa şöyle der: (24) "Evliyām, Süleymān Hūānı Beç altındaki inhizāmın işitdik ammā anıy intikāmmn pādişāhımız almak isterse ..."

Buna karşılık Evliyâ, kendi yaşadığı dönemde vuku bulan ve hezimetle sonuçlanan İkinci Viyana Kuşatması'ndan bahsetmekten bile kaçınmıştır. Sadece bir meczubun ağzından Türklerin ikinci kuşatmada Viyana'yı alamayacağını (aslında alamadığını) bildirmiştir. ${ }^{13}$ Çünkü bu kendi dönemidir, Padişah IV. Mehmet (Avc1 Mehmed) tahttadır; Evliyâ, padişaha karşı saygısızlık etmekten kaçınır, bu yüzden hezimetten bahsetmez, aksine, bir ümidini, belki küçük, sönmekte olan bir ümidini bir lafz ile dile getirir: 1100 yılında Avcı Mehmed, öteki adıyla Sulțān Yūsuf, Viyana'yı kuşatacaktır, işte o zaman Avrupalılar (Firenkler) korkmalıdır! Bunu da şem ūun-ı Șafä’nın (Simon Petrus) ağzından bir kehânet olarak söyletmiştir. şuna da iyi dikkat etmek gerek: Evliyâ bu üçüncü kuşatmada Viyana'nın mutlaka fethedileceğini söylememektedir. Galiba o, şem 'ūn-1 Șafānın ağzından “ “1100'de Firenkler korksunlar” dedirterek hem padişahı yüceltmeye hem de kendi içindeki ümit ışığını büsbütün söndürmemeye, kendisini teselli etmeye çalışıyordu.

Evliyâ'nın Seyahatnâme'de 1100 yılına ilişkin olarak Otman Baba'ya söylettikleri de bu Evliyâ Çelebi'nin "Viyana 1100 yılında feth edilecektir" inancı veya tasavvuru için ebced hesabına göre bu tarihi veren ġanim şifresini seçmiş olması rastgele değildir, bunun da bir sebebi vardır.

Evliyâ, Viyana yolculuğundan dönüşte, Kâimmakâm Mustafâ Paşa ile görüşürken ona Beç kalesinin ve daha başka önemli kalelerin nasıl fethedilebileceği hakkında düşüncelerini açıklar. Önce Kırım Hanlığı'nın ordusu ve Osmanlı ordusu fethedilecek kalenin bulunduğu yöreyi iki yıl boyunca sürekli akınlarla yağmalayıp zayıflatmalı, 
üçüncü yıl bahar yaklaşırken kale muhasara edilmelidir. Bu arada Tatar askeri Avrupa'ya akınlarını sürdürmelidir. Evliyâ'nın önemle vurguladığı nokta, bütün ganimetin askere, kalenin ise padişaha ait olacağının önceden açıklanmasıdır. şayet bu dedikleri yapılırsa, Avrupada'daki bütün şehirler fethedilebilecektir.

İki sene kāmil Budinde ve Üstolni-Belġradda ve Egre vilāyetlerinde ḳışlalar verüp yüz bin Tatar 'askeriyle ve yüz bin Āl-i 'Osmān 'askeriyle kāfiristāna çapullar verüp cemī‘i $\mathrm{i}$ kāfiriy ḳolun ḳanatların ḳırup üçüncü yılda cümle ḥāżır mühimmātlar ile hemān ḳar alaca olunca Beç ḳal'asın muĤāșara edüp yine Tatar 'askeri tā Prag̉a ve Lonçata ve İstirinyeye varınca nehb ü ġāret etmeden Hुālī olmayup iki ayda ḳal'a-i Beçi aldı yā almadı, hemān ḳış gelmeden 'askeri Beç altından çıkarup ibtidā Üstolni-Belġrad yaḳındır, ana çıḳmak gerek ki selāmet buluna. Eğer bu üslūb üzre Beç ḳal' ası muhāạara olunup 'asker ile yek-dil [ü] yek-cihet olup "Māl-ı ganā'im sizin, ḳal'a pādișāhıy" denilirse inşāallāh Beç degil, Prag̀ ve Amıstırdam ve Lonçat şehirleri bile feth olur" dedim (8. kitap, 203a 27-32). \{Tam iki yıl boyunca Budapeşte'de ve Stolni Belgrad'da ve Egre (Macarca Eger, Almanca Erlau) vilayetlerinde kendilerine kışlalar tahsis edilecek yüz bin Tatar ve yüz bin Osmanlı askeriyle hristiyan ülkelerine akınlar düzenlenmeli, bütün hristiyanların dayanma gücü (kolu kanadı) kırılmalı, üçüncü yılda karlar erimeye başlar başlamaz elde bulunan bütün silahlarla Viyana kalesi kuşatılmalı, yine Tatar askeri Prag'a, Londra'ya (?), İstirinye'ye değin akın ve çapul düzenlemeden geri kalmamalı, iki ayda Viyana kalesi ister alınmış olsun, ister alınmamış, kış gelmeden derhal asker Viyana önünden uzaklaştırmalı, ilk önce Stolni Belgrad yakındır, oraya sığınmak gerek ki güvenlik sağlansın. Eğer bu yöntemle Viyana kalesi kuşatılıp asker ile gönül birliği ve amaç birliği edilerek "Ganimet malı sizin olacak, kale padişahın olacak" denilirse, inşallah Viyana değil, Prag, Amsterdam ve Londra (?) şehirleri bile fethedilir" dedim.\} İşte Evliyâ bu yüzden, ġanīmet ile ilgili olan ganīm lafzını seçmiştir...

1100 yılı Evliyâ'nın Kızıl Elma Viyana'nın fethedileceği yıl olarak düşündüğü, tasavvur ettiği, kabul ettiği, fakat belki de sadece ümit ettiği yıldır. Seyahatnâme'nin dört yerinde böyle geçmesi bunu açıkça gösteriyor. 1683 bozgunundan pekâlâ haberi olan Evliyâ Çelebi, ümit ettiği fetih tarihini ileriye, galiba kendi ömrünün sonrasına bırakıyor.

Edirne'yi anlatmaya başlarken Evliyâ şöyle der:

Ahvāl-i taĤt-ı s̄ānī Edirne-i Yūnānī: Kavm-i Yūnānıy ikinci taHtıdır. (24) Ammā diyār-ı Almanı̀ ve bilād-ı Kızıl-Elmanıy kapusıdır. İnşāallāhu Te’ālā lafz-ı ganīmde Ḳızıl-Elma da fetḥ olur. Nite kim (25) Edirne ol diyārıy kilīdidir, Āl-i 'Oșmān țarafına bābları meftūḥdur, anlarıy daH̆ı fetiḥlerin veren Rabb-i Süb-būhdur, (26) nite kim Alman Kızıl-Elması Budin; ve Macar Kızıl-Elması Üstürgon ve Orta Macar Ḳızıl-Elması olan (27) İstolni-Belgrad fetḥ oldu, Hudā-yı Müte‘āl İşpanya Ḳızıl-Elmasını daH̆ı müyesser ede! Āmīn bi-hakḳı Seyyidi'l-Mürselīn. (28) Budin ve Belġrad ve Edirne gibi dār-1 gāaiyān sevād-ı mu'azzamlarımız elde iken inşāa allāh ganīm tārīHુinde "Ḳızıl (29) Elma ve Paris ve Ḳurțuba ve Lonçat ve Beç ve Prağ ve Donḳarḳı ve Danimarka ve Filimenke varınca feth olup (30) bu seksen yedi bin mîl cezīrei dünyāda millet-i nașāāādan bir kefere ḳalmayup cümle ümmet-i Muhammed ile (31) bu 'arșa-i ālem māl-ā-māl ola, deyü Muhyiddīnü'l-'Arabī işāret buyurmuşlardır. (Seyahatnâme, 3. kitap, 149a23-31) \{íkinci pâyitaht Yunanî Edirne üzerine: Yunan kavminin ikinci pâyitahtıdır, Alman diyarının ve Kızıl- elma Şehirlerinin giriş kapısıdır. Yüce Tanrı isterse, ganīm şifresinde (=hicrî 1100 yılında)Viyana da fetholur. Nasıl o diyarın kilidi olan Edirne'nin kapıları Osmanoğullarına açılmıştır ve onların açılmasını sağlayan Rabb-i Sübbûh'tur ve nasıl Alman Kızıl- elması Budin ve Macar Kizıl-elması Estergon (Esztergom) ve Orta Macar Kızıl- elması olan İstolni-Belgrad (Székesfehérvár, Stuhlweißenburg) feth 
olduysa, yüce Tanrı, İspanya Kızıl- elmasını da müyesser edecektir! Peygamberlerin efendisi hakkı için âmîn! Budin ve Belgrad ve Edirne gibi gaziler yatağı büyük şehirlerimiz elimizde bulunmaktayken Tanrı isterse, ganīm tarihinde (= hicrî 1100) Viyana, Paris, Kurtuba (Córdoba), Londra (?), Viyana, Prag, Dunnkirchen, Danimarka ve Felemenk'e kadar hepsi feth olunup "bu seksen yedi bin millik dünya kıtasında hristiyanlardan tek kâfir kalmayıp bu yeryüzü Muhammed ümmetiyle dopdolu olacaktır" diye Muhyiddînü'l-Arabî buyurmuşlardır.\}

Dediği özetle şudur: Eski bir Yunan başkenti olan ve Kızıl Elma şehirlerinin bulunduğu diyarın, yani Avrupa'nın kapısı olan Edirne, ondan sonra da bir dizi Kızıl Elma şehri nasıl feth olunduysa, Viyana ve öteki Kızıl Elma şehirleri de lafz-l ganīm'de, yani 1100 yılında fetholunacaktır. Ancak Evliyâ, kendisinin Seyahatnâme'yi yazdığı yıllardan yaklaşık 20 yıl sonrası için, Muhiddîn-i Arabî’nin ağzından naklettiği kehanette inşaallâh "Allâh isterse" demeyi de ihmal etmiyor.

“Ve Süleymān Ḩān zemānı Beç ḳal'ası yalın ḳat imiş, ammā şimdi (31) avcı elinden Ḩalāṣ olmuş gazāl gibi kendüyi çeküp çevirüp ol ḳadar metīn ve müstaḥkem olmuşdur (32) kim gūyā Sedd-i Ye'cūc u Me'cūc olmuşdur, (33) ta' rīf ü tavșîfden müberrādır. Ammā Ḥażret-i İsā havāriyyūnunuy şem ūn-ı Șafāsınıy rümūzunda "zılle tārīĤinde Süleymāndan (33) ḳorḳmay" dedigi gelüp zuhūr edüp hịmet-i Huudā Süleymān Hुān bīfeth ' 'avdet etdi, ammā inşāallāh ġānim ve daḤı ġanīm lafẓı tārīHinde (34) 'Oșmānlı bu kal'ayı muhāsara etmeleri muḳarrerdir. Hudā fetḥin müyesser ede!” (Seyahatnâme, 7. kitap, 55b30-34) \{Süleyman Han zamanında Viyana Kalesi yalınkat imiş, ancak şimdi avcı elinden kurtulmuş ceylan gibi kendisini çekip çevirip o kadar sağlam ve korunaklı olmuştur ki, sanki Çin Seddi olmuştur; bu kaleyi anlatacak, niteleyecek söze gerek yoktur. Hz. İsa havarîlerinden Simon Petrus'un rumuzunda “ẓlle tarihinde Süleyman'dan korkmayın" dediği gelip geçti, doğru çıktı; neden öyle olduğunu Tanrı'dan başkası bilmez, Süleyman Han fetihsiz geri döndü, ama inşallah, gānim şifresi (= hicrî 1091) ve ġanim şifresi (= hicrî 1100) yıllarında Osmanlıların bu kaleyi kuşatacakları kesindir. Tanrı fethini sağlasın!"\}

Evliyâ Çelebi, Seyahatnâme 6. kitap 73b ve devamında Budin'i anlatırken hangi Avrupa şehirlerinin Kızıl-elma şehirleri olarak kabul edildiği üzerine bilgi verir, bu arada Tanrı rızası olmadığı için Kanûnî Sultan Süleyman'ın Viyana'yı fethedememiş olduğunu da belirtir: ammā riżā-yı Hudāa (8) olmadugiundan kal' a-i Beçi Süleymān Hुān feth edemeyüp bifetḥ 'avdet edüp kal' a-i Cān Kurtaranda cān kurtardı (Seyahatname, 6. kitap,74a7-8).

Yukarıdaki alıntıda, Evliyâ'nın kuşatılıp da alınamayan Viyana için kullandığı "avcı elinden kurtulmuş gazal gibi” benzetmesi pek güzeldir. Okuduğum metinlerde böyle bir benzetmeye rastlamış olduğumu hatırlamıyorum. Danıştığım klasik edebiyat uzmanları da bunun divan edebiyatının klişe benzetmelerinden biri olmadığ konusunda birleştiler. Ceylan ile ilgili düzinelerce benzetme vardır, ama muhasaradan kurtulmuş bir kalenin "avcı elinden kaçmış gazal" a benzetilmesi olağanüstü bir şeydir. Orijinal olduğunu, kendisinin bulduğunu sandığım bu benzetmeyi Evliyâ iki yerde daha kullanmıştır:

(IV.317b1) Kạl'a-i Bāg̀-1 Cinān: 'Irāḳ-1 'Acemde Muṣul Ḩākiyle Hemedān mābeyninde bir șa $\mathrm{b} b$ (2) $u$ çengelistān u Hुıyābān içre bir yalçın püşte-i bülend üzre kehkeşān-āsā semāya ser çekmiş bir ḳal'a-i ser-bülend, Bāg̀-1 Cinān-1 cihāndır [...] (13) bu kal'a-i Bāg̀-1 Cinān Hुusrev-i şīr-i gurrende vü dirrende pençesinden rehā bulmuş yaralı ve maralı ( merālī) gazāl gibi Hualāṣ olup ilā hāze'l-ān dest-i 'Acemde kalmışdır. \{Bâğ-ı Cinân Kalesi: Irâk-1 Acemde Musul toprağıyla Hemedân arasında sarp ve ormanlık bir bölge içerisinde yalçın ve yüksek bir tepe üzerinde ebemkuşağı 
gibi gökyüzüne uzanmış bir yüksek kale, dünyanın Bâğ-ı Cinân'ıdır ( cennetler hahçesidir) [...] (13) bu Bâğ-1 Cinân Kalesi, kükreyen yırtıcı aslan Husrev'in (IV. Murâd'ın veziri Serdâr Husrev Paşa) pençesinden kurtulmuş yaralı ve maralı ( merâlî) ceylan gibi kurtulup bugüne kadar Acem (İranlılar) elinde kalmıştır. ${ }^{14}$

(VIII.351b29) Evșāf-ı cezīre-i kaal'a-i Körfös : Körfez daHnı derler.[...] (30)... sene 943 tārīHูinde Süleymān Hān elinden gazāl ḳurtulur gibi bu kal'a Halāṣ olaldan berü eyle metīn ü müstahkem bir ḳal'a-i üstüvār etmişlerdir kim vāḳı'asında bu kal'ayı görenleriy dudaḳları uçuḳlar. \{Körfös Kalesi Adası hakkında: Körfez de derler.[...] Bu kale 943 yilında Süleyman Han'ın elinden ceylan kurtulur gibi kurtulduğundan beri öylesine sağlam ve korunaklı, güvenli bir kale haline getirmişler ki, bu kaleyi rüyasında görenlerin korkudan dudakları uçuklar.\}

\section{EK}

\section{SEYAHATNÂME'DE VIYANA'NIN FETHINNE IILİşKIN OLARAK}

\section{TARIHINNIN, 1100 TARIHININ VE/ VEYA ĠANĪM şIFRESINNIN GEÇTiĞí YERLER} 1094

(VII.53a21-24) ... İnşāa allāh yine bizim içün ma mûr olmuşdur. Hูudā yine dest-i İslāma müyesser ede" dedigimde bir büdelā şekilli çāşnigīr ādem eydir: Allāh bu bāg̉ı ve kal' a-i Beçi doksan dördde İslām eline vermeye, zīrā bu bināları cümle Hูarâb ederler, dedikde gözleri țās-1 pür-Hūna döndü. Bir mecāzibūndan kimesne idi, ammā Allāh an-ḳarībü'zzemān 'asker-i İslāmı k kudūmiyle bu şehir Ḩākine ḳadem bașmağı müyesser ede! Âmīn.

\section{0 (lafẓ-1 ganīm)}

(III.149a23) "Ahvāl-i taht-ı sānī Edirne-i Yūnānī: Kavm-i Yūnānıy ikinci tahtıdır. (24) Ammā diyār-ı Almanıy ve bilād-ı Ḳızıl-Elmanıy kapusıdır. İnşāallāhu Teālā lafẓ-ı ġanīmde Ḳızıl-Elma da fetḥ olur. Nite kim (25) Edirne ol diyārıy kilīdidir, Āl-i 'Osmān tarafına bābları meftūhdur, anlarıy dahı fetihlerin veren Rabb-i Sübbūḥdur. (26) Nite kim Alman Ḳızıl-Elması Budin; ve Macar Ḳızıl-Elması Üstürgoon ve Orta Macar ḲızllElması olan (27) İstolni-Belg̀rad fetḥ oldu. Hुudā-yı Müte āl İşpanya Ḳızıl-Elmasını daḨı müyesser ede! Āmīn bi-hakḳı Seyyidi'l-Mürselīn.(28) Budin ve Belg̀rad ve Edirne gibi dār-1 gaāziyān sevād-ı mu'azzamlarımız elde iken inşāallāh ganām tārīḤinde "Ḳızl-(29) Elma ve Paris ve Kurțuba ve Lonçat ve Beç ve Prag ve Donḳarḳız ve Danimarḳa ve Filimenke varınca feth olup (30) bu seksen yedi bì mīl cezīre-i dünyāda millet-i nașārādan bir kefere ḳalmayup cümle ümmet-i Muhammed ile (31) bu 'arṣa-i ālem mālā-māl ola, deyü Muhyiddinü'l-'Arabī işāret buyurmuşlardır."

(VII.55a, satır 31) Ṣoyra lafẓ-1 gaānim tārīHinde lafẓ-1 ganīm tārīHuinde Sulțān Yūsuf Mehemmed-i zemān (32) gelmesinden pek ḳorḳup Muhammedīler ile șulh edin deyü şem 'ūn-1 Șafā bu kal'a-i Beç içün niçe rümūz-1 künūzlar söyleyüp

(VII, 55b30) “Ve Süleymān Hān zemānı Beç kal'ası yalın ḳat imiş, ammā şimdi (31) avcı elinden Ḩalāṣ olmuş gazāl gibi kendüyi çeküp çevirüp ol ḳadar metīn ve müstaḥkem olmuşdur (32) kim gūyā Sedd i Ye'cūc u Me'cūc olmuşdur, (33) ta'rīf ü tavșîfden müberrādır. Ammā Ḥażret-i Îsā ḥavāriyyūnunuy şem ūn-1 Ṣafāsınıy rümūzunda "ẓlle tārīHinde Süleymāndan (33) ḳorḳmay” dedigi gelüp zuhūr edüp hikmet-i Hudā Süleymān Huān bì-feth 'avdet etdi, ammā inşāallāh g̉ānim ve dahı ġanīm lafzı tārīhinde (34) 'Osmānlı bu ḳal'ayı muhāsara etmeleri muḳarrerdir. Huudā fetḥin müyesser ede!”

1100 (ba'de'l-elf mi'e) 
(VIII.379a17) Ve Rūmeli kāfiristānında İşpanya ve Nemse ve Donḳarḳız (18) ve Danimarḳa ve Rimpapa ve Paris vilāyetlerin geșt ü güzār ederken "ỉlāhī İslām diyārı olup kenīseler, ma 'bedgāh-1 müslimīn ola (19) ba 'de'l-elf mi' e” deyü nefes etmişlerdir.

\section{NOTES}

1. Elbette her eserde olduğu gibi Seyahatnâme'de de yazıcı yanlışları, atlamalar vb. vardır. Dankoff, yazarın eseri bir yardımcısına yazdırdığı, sonra baştan aşağı dikkatle gözden geçirmiş, düzeltme ve eklemeler yapmış olduğu hakkında kanıtlar ortaya koymuştur. Ancak, o sırada yaşı yetmişne yaklaşmış olan Evliyâ'nın gözlerinin ve dikkatinin bütün yazıcı yanlışlarını yakalayabilecek kadar kuvvetli olduğuna ihtimal verilebilir mi?

2. Koçu, Reşad Ekrem. Evliyâ Çelebi Seyahatnamesi I, (İstanbul [tarihsiz, belki 1943]). Koçu, s. 11'de İstanbul baskısı, 7. kitap, s. 286'dan bir alıntı yapar, burada Evliyâ, Fâzıl Ahmed Paşa'dan sonra Merzifonlu Kara Mustafa Paşa'nın sadrazam olduğunu anlatmaktadır. Bundan sonra Koçu şöyle der: “Bu kayıttan Evliyâ'nın 1683'e doğru, Viyana bozgunu felâketini görmeden öldügünü anliyoruz."

3. Özellikle, 7. kitapta Otāg̀-ı Süleymān'ı anlatırken Viyana'nın țoksan dördde (yani miladî 1683'te) fethedilemeyeceğine dair bir meczûbun ağzından duyurduğu kehâneti kastediyorum; bunun için aşağıya bkz.

4. Seyahatnâme üzerine derinlemesine çalışmış olan Richard F. Kreutel'in bu konuda çalışmaları sayıca azdır, yayımlanış sırasına göre şunlardır:

"Ewliyà Čelebīs Bericht über die türkische Grossbotschaft des Jahres 1665 in Wien. Ein Vergleich mit zeitgenössichen türkischen und österreichischen Quellen.” \{Evliyâ Çelebi'nin 1665'te Viyana'ya gönderilen Türk elçilik heyeti üzerine yazdıkları. Aynı dönem Türk ve Avusturya kaynakları arasında bir karşılaştırma\} Wiener Zeitschrift für die Kunde des Morgenlandes 51, 1948, 188-242. Eşitbasım: Sezgin, yay. 2008, III, 90-144].

Im Reiche des goldenen Apfels. Des türkischen Weltenbummlers Evliyâ Çelebi denkwürdige Reise in das Giaurenland und in die Stadt und Festung Wien anno 1665. \{Kızılelma diyarında : Türk dünya gezgini Evliyâ Çelebi'nin 1665 yılında gâvur memleketine ve Viyana şehri ile kalesine yaptığı önemli seyahat\} Graz Acta Orientalia Hungaricae 10 (1960) 308-10; Kálman Benda, Századok 94 (1960), 428], 1957 [2. bsk. 1963; Erich Prokosch ve Karl Teply tarafından gözden geçirilip genişletilmiş baskı (stark vermehrte Ausgabe besorgt von Erich Prokosch und Karl Teply) 1987]

"Neues zur Evliyā-Çelebī-Forschung." \{Evliyâ Çelebi araştırmalarında yeni kazanılan bilgiler\} Der Islam 48, 1972, 269-79. "Evliyâ Çelebi." Biographisches Lexikon zur Geschichte Südosteuropas (München, 1974) içerisinde: 480 ve dev.

5. غ̇ānim ; غنم : غانم : غ غ 1090

6. Im Reiche des goldenen Apfels, 2. bsk, 1963, 228.

7. Kreutel, Kilisli Rifat'ın baskıya hazırladığı 7. cildi kullanmıştır. Rifat [Bilge] orada (s. 248) metni şöyle düzenlemişti :

(غانم) لفظ تاريخنده و [؟] (غنم) لفظ تاريخنده يوسف ن سلطا محمد زمان كلمه سندن قورقوب يك

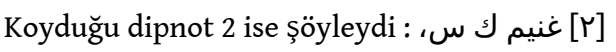

Kilisli Rifat Bey burada, س (sin) rumuzunu “Saray nüshası", yani Topkapı Sarayı Kütüphanesi, 
Bağdat 308 no.lu yazma için; ) 5 kef) rumuzunu da kendisinin "güzel yazma" diye söz ettiği Topkapı Sarayı Kütüphanesi, Revan 1458 no.lu yazma için kullanmıştır; rumuzları 7. cilde yazdığı mukaddime'nin (ح) sayfasında açıklamıştır.

8. Evliyâ Çelebi Seyahatnamesi, Topkapı Sarayı Kütüphanesi Bağdat 308 Numaralı Yazmanın Transkripsiyonu - Dizini. 7. Kitap. YKY İstanbul 2003, s. 96.

9. Dankoff'a göre Evliyâ tarafından titizlikle gözden geçirilip düzeltilmiş ve eklemeler yapılmıştır.

10. Dankoff, Seyahatnâme'de yaklaşı 485 yerde bu eklemeyi gerekli görmüş ve yapmıştır.

11. Yuvarlak sayılar son zamanlara kadar önemli sayılmıştır. Bu satırların yazarı da çocukluğunda "kıyamet" için "Bin üç yüzde olmaz, bin dört yüze kalmaz" veya "Bin dört yüzde olmaz, bin beş yüze kalmaz" dendiğini birçok kez duymuştur. şüphesiz bugün bile böyle saçmalıklara inananlar vardır.

12. YKY baskısındaki [sız] eklemesi gereksizdir; burada sulțānım hitap değil, özne olarak anlaşılmalıdır: “Benim efendim Beç'i ne diye soruyor?”. Yaptığım tarama sonucuna göre Seyahatnâme'de 2. çoğul kişi eki -sız/siz hiçbir yerde eksik yazılmamıştır.

13. Yukariya bkz.

14. IV. Murâd'ın Bağdat seferi sırasında, hicrî 1039'da Osmanlı ordusuna direnişsiz teslim edilen kalenin sonradan tekrar İranlıların eline geçmiş olduğu anlatılmakta.

\section{RÉSUMÉS}

Before the publication of Richard Kreutel's important work on the Vienna account in Volume 7 of the Seyahatnâme it was thought that Evliyâ Çelebi was unaware of the second siege of Vienna (1683). The Austrian scholar showed that he was aware of this defeat. Evliyâ learned about it in the last years of his life but probably had no detailed knowledge of it and did not narrate it in his work. Only, while relating his experiences when he was in Vienna in 1665 as a member of the Ottoman delegation, he announced the defeat to his readers using a fictional technique: a prophecy, in the form of a negative wish from the mouth of an ecstatic, that the siege that would take place eighteen years later would be unsuccessful (VII.53a21-24).

There is one item lacking in Kreutel's work: Evliyâ Çelebi did not speak openly of a third attempt to conquer Vienna to be made in the future, but he did express this in several places using coded language. Kreutel was unaware of this because of the philological problems connected with the old edition of the Seyahatnâme and because he did not read all ten volumes of the work.

In various places of the Seyahatnâme there are notices about a Turkish siege of Vienna the "Red Apple" (Kizılelma), prophecies and warnings as to whether or not the city would be taken, dates of past and future sieges, and codes to decipher these dates. Bringing all of this material together, we can make the following determinations.

Based on what he read and heard, Evliyâ gave a detailed account of the first siege of Vienna in 1529 , emphasizing that it was a tremendous rout. When he was making the final redaction of his work in the 1680s, 155 years had passed since this event and there was no reason for him to be hesitant about it.

It is possible that he had little information about the second siege of Vienna in 1683; but a person like him, who loved to tell stories, could still write something about it. His failure to narrate anything on this topic, only putting it like a prophecy in the mouth of an ecstatic as a wish that 
the attempt would be unsuccessful, is perhaps due to the fact that the wounds of this defeat were still very fresh. Perhaps Evliyâ did not discuss this failure and the reasons for it in order not to pay any disrespect for Sultan Mehmed IV, who was still alive and reigning.

Evliyâ Çelebi had, if not a belief, at least a hope that in the year 1100 of the Hijra Mehmed IV would again try to conquer Vienna and that this attempt would be successful; but this hope was fading. Evliyâ expressed the hope, in several places of his work, in a code using the abjad system of dating (in which the Arabic letters stand for numbers): lafz-1 ganim $=1100 \mathrm{H}=1688 / 89 \mathrm{CE}$. He also put the wish that Vienna (and other "Red Apple" cities) be conquered in $1100 \mathrm{H}$ in the mouth of the legendary shaikh Oșmān Baba. Evliyâ introduces this shaikh, known in other sources as Otmān Baba, as one of the ghazis who came from Turkistan in the time of Orhan Bey and undertook the conquest of Rumelia. He traveled through the countries of Europe and prayed that Islam would spread everywhere he went. According to the Seyahatnâme, the founder of Vienna was şem'ūn-1 Șafā (St. Peter), one of Jesus's disciples. He too made a prophecy, telling the Christians that they should not be afraid of the siege undertaken by Igrando Süleymān in $935 \mathrm{H} \mathrm{(=}$ lafz-1 zille $=1528 / 29 \mathrm{CE}$ ) but that they should be afraid of the campaign of Mehmed IV (also known as Yûsuf) in $1100 \mathrm{H}$.

When Evliyâ wrote the Seyahatnâme, the year 1000 H (the Islamic millennium, 1591/92 CE) had long passed. In his work he nowhere mentions the year $1000 \mathrm{H}$ or the events that were expected to happen in that year but did not take place. As he was making the final redaction of his work the year $1100 \mathrm{H}$ was approaching. It would be naïve to think that Evliyâ Çelebi actually believed that certain important events would take place in the year $1100 \mathrm{H}$ and that the "Red Apple" Vienna would be conquered. Perhaps he used this date and the coded abjad word for it, ganim, to express a hope that was fading. In so doing, he showed literary skill by placing the prophecies of two holy men - one Muslim, the other Christian - regarding the future Turkish conquest of Vienna in widely separated parts of his work (Oșmān Baba, Volumes 3 and 4; şem'ūn-1 Șafāa, Volume 7).

Avant la publication de l'important travail de Richard Kreutel sur Vienne dans le volume $7 \mathrm{du}$ Seyahatnâme, on pensait qu'Evliyâ Çelebi n'était pas au courant du second siège de Vienne (1683). Le chercheur autrichien a montré qu'il connaissait cette défaite. Evliyâ en entendit parler dans les dernières années de sa vie, mais probablement, n'en a pas eu une connaissance détaillée et ne l'a pas racontée dans son œuvre. Mais, en relatant ses expériences de 1665 quand il était à Vienne comme membre de la délégation ottomane, il annonça la défaite à ses lecteurs en utilisant une technique de fiction, une prophétie sous forme d'un vœu négatif fait par la bouche d'un homme en extase, selon laquelle un siège qui aurait lieu dix-huit ans plus tard serait un échec (VII.53a21-24).

Une chose manque dans le travail de Kreutel: Evliyâ Çelebi n'a pas ouvertement parlé d'une troisième tentative de conquête de Vienne à l'avenir, mais il l'exprima en plusieurs endroits en langage codé. Kreutel n'était pas au courant des problèmes philologiques liés à la vieille édition du Seyahatnâme et, à cause de cela, n'a pas lu en entier les dix volumes de l'œuvre.

En différents endroits du Seyahatnâme, il y a des mentions d'un siège turc de Vienne, la « Pomme rouge », (Kızılelma), des prophéties et avertissements sur le fait de savoir si la ville serait prise ou non, les dates de sièges passés et futurs et des codes pour déchiffrer ces dates. En réunissant tout ce matériel, nous pouvons faire les affirmations ci-dessous.

En se fondant sur ce qu'il vit et entendit, Evliyâ nous donna un récit détaillé du siège de Vienne en 1529, en insistant sur la terrible déroute. Quand il fit sa rédaction finale dans les années 1680 , 155 ans s'étaient écoulés depuis l'événement et il n'avait plus aucune raison d'hésiter.

Il est possible qu'il n'ait eu que peu d'informations sur le second siège de Vienne en 1683 ; mais quelqu'un comme lui, qui adorait raconter des histoires, pouvait tout de même écrire à ce sujet. Son absence de récit à ce sujet, mis seulement dans la bouche d'une personne en extase comme 
une prophétie, comme le vœu que la tentative soit un échec, est peut-être due au fait que les blessures de cette défaite étaient très fraîches. Peut-être n'a-t-il pas discuté de cet échec ni de ses raisons pour ne pas manquer de respect envers le Sultan Mehmed IV, encore en vie et régnant. Evliyâ Çelebi avait, sinon la certitude, du moins l'espoir que dans l'an 1100 de l'Hégire, Mehmed IV réessayerait de conquérir Vienne et que cet essai serait couronné de succès. Il exprima cet espoir, en plusieurs endroits de son travail, dans un code qui utilisait le système abjad de datation (dans lequel les lettres arabes remplacent les nombres) : lafz-1 ganīm $=1100 \mathrm{H}=1688 / 89$ CE. Il mit aussi le souhait que Vienne (et d'autres villes « Pomme rouge ») soit conquise en $1100 \mathrm{H}$ (= de l'Hégire) dans la bouche du cheikh légendaire Oșān Baba. Evliyâ présente ce cheikh, connu par d'autres sources comme Otmān Baba, comme l'un des ghazis qui vint du Turkestan à l'époque d'Orhan Bey et entreprit la conquête de la Roumélie. Il voyagea à travers l'Europe et pria pour que l'Islam se répande partout. Selon le Seyahatnâme, le fondateur de Vienne était şem ūn-1 Ṣafā (Saint-Pierre), l'un des disciples de Jésus. Il fit aussi une prophétie qui disait aux chrétiens de ne pas craindre le siège entrepris par Iǵrando Süleymān in 935 H (= lafẓ-1 ẓlle = 1528/29 CE), mais de redouter la campagne de Mehmed IV (connu comme Yûsuf) en $1100 \mathrm{H}$.

Quand Evliyâ écrivit le Seyahatnâme, l'an 1000 H (1591/92 selon l'ère islamique) était loin. Dans son travail il ne mentionne nulle part l'année $1000 \mathrm{H}$ ou les événements qui étaient attendus, mais qui ne se sont pas produits. Quand il travailla à sa rédaction finale, l'année $1100 \mathrm{H}$ était proche ; il aurait été naïf de croire que des événements importants allaient avoir lieu en $1100 \mathrm{H}$ et que Vienne, la "pomme rouge ", serait conquise. Peut-être a-t-il employé cette date et le mot pour elle en code abjad, ganīm, pour exprimer un espoir qui s'effaçait. Ce faisant, il faisait montre d'habileté littéraire en plaçant les prophéties sur la future conquête de Vienne de deux saints hommes, l'un musulman, l'autre, chrétien, dans deux parties largement distinctes de son œuvre (Oșmān Baba, volumes 3 et 4 ; şem 'ūn-1 Ṣafā, Seyahatnâme'nin VII. cildindeki Viyana anlatısı üzerine Richard Kreutel'in önemli çalışması yayımlanmadan önce Evliyâ Çelebi'nin İkinci Viyana Kuşatması'ndan (1683) haberi olmadığı sanılmaktaydı. Avusturyalı bilgin, onun bu bozgundan haberi olduğunu ortaya çıkardı. Evliyâ, hayatının son yıllarında öğrendiği, fakat herhalde ayrıntıları hakkında fazla bilgi edinemediği bu yenilgiyi eserinde anlatmamıştır. Sadece, Osmanlı elçilik heyetinin bir üyesi olarak 1665 'te Viyana'da bulunduğu sırada yaşadıklarını anlatırken bir tür kurgulama tekniği kullanarak 18 yıl sonra vuku bulacak kuşatmanın başarısız sonucunu, bir meczubun ağzından olumsuz dilek tarzında bir kehanetle okuyucusuna duyurmuştur (VII. 53a21-24).

Kreutel'in çalışmasında bir eksik vardır: Evliyâ Çelebi, Viyana'nın fethedilmesi için ileride yapılacak üçüncü bir girişimden açıkça söz etmemiş, fakat bunu birkaç yerde şifreli bir anlatımla ifade etmiştir. Seyahatnâme'nin eski edisyonundan kaynaklanan filolojik bir sorun yüzünden ve on ciltlik eserin tamamını okumamış olması yüzünden Kreutel bunun farkına varmamıştır.

Seyahatnâme'nin değişik yerlerinde Kızılelma Viyana'nın Türkler tarafından muhasarası üzerine bilgiler, şehrin fethedileceği veya edilmeyeceği üzerine kehanet ve uyarılar, geçmişteki ve gelecekteki muhasaraların tarihleri, bu tarihleri veren şifreler bulunmaktadır. Bunların hepsini bir araya getirince şu belirlemeleri yapabiliriz: Evliyâ, okuduklarına ve işittiklerine dayanarak Birinci Viyana Kuşatması'nı ayrıntılı olarak anlatmış, bu kuşatmanın büyük bir hezimet olduğunu da açıkça vurgulamıştır. 1680'lerde eserinin son redaksiyonunu yaparken bu olay üzerinden en az 155 yıl geçmiş bulunmaktaydı, çekingen davranmasını gerektiren bir sebep yoktu.

Yazar, İkinci Viyana Muhasarası hakkında fazla bilgi toplayamamış olabilir, ama onun gibi anlatmayı çok seven birisi, yine de bir şeyler yazabilirdi. Bu konuda hiçbir şey anlatmayışı, sadece bir meczubun ağzından bu girişimin başarısız kalması dileğini bir kehanet gibi söyletişi, belki bu hezimetin yaralarının çok taze olması yüzündendi. Evliyâ, henüz hayatta ve iktidarda olan padişah IV. Mehmed'e karşı hürmetsizlik etmemek için bu başarısızlıktan, bunun 
sebeplerinden söz etmemiş olabilir.

Hicrî 1100 yılında IV. Mehmed'in Viyana'yı tekrar feth etme girişiminde bulunacağı ve bu girişimin başarıyla sonuçlanacağı hususunda Evliyâ Çelebi'nin bir inancı değilse bile, en azından bir ümidi, belki sönmekte olan bir ümidi vardır. Evliyâ, bu ümidini eserinin birkaç yerine ebced hesabına göre düzenlendiği bir şifre ile yerleștirmiştir (lafẓ-1 ġanīm = hicrî $1100=$ milâdî 1688/89). Ayrıca Viyana'nın (ve başka Kızılelma şehirlerinin) hicrî 1100'de fetholunması dileğini, efsanevî şeyh Oșmān Baba'nın ağzından da söyletmiștir. Adı başka kaynaklarda Otmān Baba olarak geçen bu şeyhi Evliyâ, Orhan Bey zamanında Türkistan'dan gelip Rumeli fethine girişen gazilerden biri olarak tanıtır. Avrupa ülkelerini dolaşmış, her yerde İslam'ın yayılması için dua etmiştir. Seyahatnâme'ye göre Viyana'nın kurucusu, Hz. İsa'nın havarilerinden şem 'ūn-ı Șafā'dır (Simon Petrus). O da kehanette bulunmuş, hristiyanlara, Ig̉rando Süleymān'ın hicrî 935'te (= lafẓ-1 ẓlle = miladî 1528/29) yapacağı kuşatmadan korkmamalarını, fakat IV. Mehmed'in (diğer adıyla Yûsuf'un) hicrî 1100'deki seferinden korkmalarını bildirmiştir.

Evliyâ, Seyahatnâme'yi yazdığı sırada, hicrî 1000 yılı (İslam millenniumu, 1591/92) çoktan geride kalmıştı. Yazar, hicrî 1000 yılından ve o yıl vuku bulması beklenmiş, fakat vuku bulmamış olaylardan hiç bahsetmez. O, Seyahatnâme'sinin müsveddesini hazırlamaktayken hicrî 1100 yılı yaklaşıyordu. Evliyâ Çelebi'nin hicrî 1100 yılında bazı önemli olaylar vuku bulacağına, Kızılelma Viyana'nın fethedileceğine gerçekten inandığını kabul etmek herhalde safdillik olur. 0 , bu tarihi ve bunun şifresi olan ganīm kelimesini yüreğinde sönmekte olan bir ümidi ifade etmek için kullanmış olabilir. Bunu yaparken biri müslüman, öteki hristiyan iki azizin Viyana'nın gelecekte Türkler tarafından fethedileceği hususunda birleşen kehanetlerini eserinin birbirinden uzak yerlerine (Oșmân Baba, III ve VIII cilt; şem'ūn-ı Safa, VII. cilt) yerleştirerek edebi maharet göstermiştir.

\section{INDEX}

Thèmes : Histoire, Histoire des mentalités motsclestr Evliyâ Çelebi (1611-1682), Seyahatnâme, Kizilelma, Kreutel Richard (1916-1981), Viyana Kuşatması, Osmanlı İmparatorluğu, Onyedinci yüzyılda, Tarih, Zihniyetlerin Tarihi, Seyahatnameler

Mots-clés : Evliyâ Çelebi (1611-1682), Evliyâ Çelebi (1611-1682), Seyahatnâme, Seyahatnâme, Pomme rouge, Pomme rouge, récit de voyage, Kreutel Richard (1916-1981), Kreutel Richard (1916-1981), sièges de Vienne

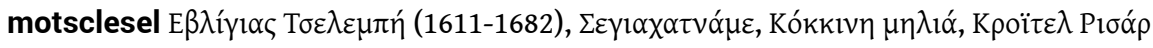

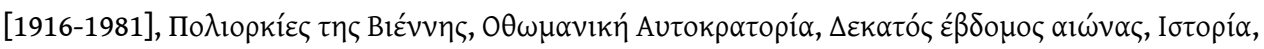

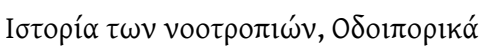

Keywords : Evliyâ Çelebi (1611-1682), Seyahatnâme, Red Apple, Kreutel Richard (1916-1981), siege of Vienna, Ottoman Empire, seventeenth century, History, travelogues

motsclesmk ЕВЛИЈА ЧЕЛЕБИЈА, (1611-1682) СЕЈАХАТНАМЕ, ЦРВЕНО ЈАБОЛКО, КРЕЈТЕЛ РИЧАРД

(1916 1981), СЕДИШТА ВИЕНА, ОТОМАНСКАТА ИМПЕРИЈА, СЕДУЧИАЕСЕТИОТ ВЕК, ИСТОРИЈА, ИСТОРИА НА МЕНТАЛИТЕТ, ПАТЕПИСИ

Index géographique : Empire ottoman

Index chronologique : dix-septième siècle 
AUTEUR

SEMIH TEZCAN

Professeur

Université Bilkent, Ankara 